\title{
Variability of Large Seeded Faba Bean Genotypes for their Yield and Yield Components in Water Logging Areas of Southern Tigray, Ethiopia
}

\author{
Birhanu Amare Gidey \\ Alamata Agricultural Research Center, Pulse and oil Cros Case team, Tigray, Ethiopia.
}

\begin{abstract}
Hashenge and Aiba in 2015 to evaluate the variability of large seeded faba bean genotypes for their yield and yield components in water logging areas. Alpha lattice design with two replications was used for the experiment. ANOVA has showed high statistical significant difference $(P<0.01)$ for thousand seed weight over locations. Based on this, genotype EH 06007-2 scored highest 1000 seed weight (1111gm) followed by EH 06088-6 (971.5) and EH 06007-4 (938.5 gm) over locations. But least seed weight was obtained from the local genotype $(505.5 \mathrm{gm})$ followed by the standard check Walki (587.3) and ET 07017-bulk $(648.0 \mathrm{gm})$ genotypes. Moreover, grain yield has also showed significant difference $(p<0.05)$ at Aiba location but no significant difference in the other location (Hashenge). At Aiba, genotype ET 07013-1 gave the highest grain yield (59.31 qt/ha) followed by genotype ET 07005-1 (57.85) and EH 06088-1 (54.77 qt/ha). Significant positive correlations were also recorded TSW with DM (0.624), number of seeds per pod (0.567) and NTPP (0.427) but it was negatively correlated with NPPP (0.487). Grain yield was significantly and positively correlated with plant height (0.49) and NPPP (0.369). The highest distance (0.692) was between cluster $V$ and $I V$, which suggested that the members of these clusters diverge on most of the studied traits and could be used in breeding programs. Principal component (PC) analysis revealed that the first four PCs having eigenvalues $>1$ explained $83.7 \%$ of the total variation. The variance explained by PC1 was mostly due to traits related to DM, TSW, NSPP and NTPP, whereas PC II was mostly related to grain yield, plant height, NPPP and thousand seed weight traits. In this experiment, the PC analysis ultimately showed the amount of variability for the traits that could be used for the improvement of large seed sized faba bean genotypes
\end{abstract}

Keywords: faba bean, Genotypes, grain yield, Large seed size.

Abbreviations: DM: Days to maturity; NTPP: Number of Tillers per Plant; NPPP: Number of pods per plant; NSPP: Number of seeds per pod; TSW.

\section{INTRODUCTION}

Faba bean is known to grow in various parts of the world including Ethiopia and it is the $2^{\text {nd }}$ largest producer next to China (Biruk, 2009). According to the CSA (2013) data, faba bean grows in the highland areas of the northern and central Ethiopia and the total cultivated area and average yield of the crop in 2008/2009 was 538, 820.5 ha and $12.92 \mathrm{qt} / \mathrm{ha}$, respectively. Based on this, Tigray region shares $4.11 \%$ in area coverage (22870.56 ha) next to Amhara $(48.05 \%)$, Oromia $(37.46 \%)$ and SNNPR (10\%).

Faba bean (vicia faba L.) is one of the major pulse crops grown in the highlands $(1800-3000 \mathrm{~m}$ asl) of Ethiopia (Temesgen and Aemiro, 2012). Faba bean is a valuable protein-rich leguminous crop cultivated and consumed as human food in the specified areas. In addition, its straw is used as animal feed. With a cheap protein source, it partly compensates for the large deficiency in animal protein sources. Faba bean plays a significant role in improving the productivity of soil by fixing atmospheric nitrogen and is a suitable rotation crop for cereals. A major benefit of rotating pulse crops, such as faba bean with cereal crops is in compensation or response to low soil fertility as well as in the interruption of diseases and insect pest cycles (Barri and Shtaya, 2013).

Vertisols cover $10.3 \%$ (about 12.7 million ha) of the Ethiopian land mass and are the fourth most abundant soils after Histosols, Cambisols and Nitosols and it is estimated that Vertisols comprise about $24 \%$ of all cropped highland soils (Tekalign et al., 2002). Vertisols are potentially among the most productive soils of sub-Saharan Africa, but they are agriculturally underutilised within the 
traditional farming practices due to excess soil moisture from water logging during heavy rains. High moisture level limits faba bean production on vertisol as the crop is highly sensitive to water logged condition (Getachew et al., 2003). The problem of black root rot (Fusarium solani) is widely prevalent in the vertisols where it is mainly associated with water logging (Beniwal and Dereje, 1987).

The highland area of Southern Tigray is potential not only for faba bean but also for other pulse crop production. In spite of its importance, however, the production and productivity is by far below the genetic potential of the crop (MoARD, 2008). Less access of improved varieties and susceptibility of the available varieties of faba bean to water logging becomes the most important constraint in the highland areas of southern Tigray where faba bean is widely grown. The problem of water logging is not only resulted to root rot but also for outbreaks of chocolate spot and ascochyta blight (Couchman.and Hollaway, 2016). Currently, vertisols are difficult to manage due to their poor internal drainage and resultant flooding and water logging during the wet season. As a result, vertisols in southern Tigray are currently underutilized and largely used for dry season grazing. The objective of this study was to select genotypes that have large seed size, high grain yield and tolerate diseases infestation in vertisol areas.

\section{MATERIALS AND MeTHODS}

\subsection{Description of Study Area}

The experiment was conducted at Hashenge and Aiba, Souhern zone of Tigray Regional State, Ethiopia that located 148 and $102 \mathrm{kms}$ far south of Mekelle (capital city of Tigray) in that order. These locations have an altitude of 2420 and $2700 \mathrm{~m}$ asl respectively and the soil of the testing fields was clay (vertisol). The studyareas were selected based on representativeness (potential) for faba bean production and experienced in water logging condition.

\subsection{Experimental Materials and Methods}

The materials used in this experiment were comprised of 32 large seed size Faba bean genotypes (New, EK 05024-2, EK 05023-1, EK 05014-3, EK 05027-5, EK 05002-3, EK 05005-4, ET 07002-1, ET 07002-2, ET 07002-bulk, ET 07005-1, ET 07005-2, ET 07005-3, ET 07005-bulk, ET 07013-1, ET 07017-bulk, ET 07019-bulk, EH 06007-2, EH 06007-4, EH 06088-1, EH 06031-3, EH 06023-4, EH 06022-4, EH 06022-1, EH 06028-1, EH 06070-3, EH 06007-6, EH 06022-3, EH 06088-6 as well as Hachalu. Walki and local). These materials were sourced from Holleta Agricultural research center in 2014. The experiment was designed in Alpha Latice Design with two replications and plots of $2 \mathrm{~m}$ long and $2.4 \mathrm{~m}$ wide spaced 40 and $10 \mathrm{~cm}$ between rows and plants, respectively was used. Four rows were harvested for yield and yield component evaluation In addition, $46 \mathrm{~kg} / \mathrm{ha} \mathrm{P} 2 \mathrm{O} 5$ and $18 \mathrm{~kg} / \mathrm{ha}$ nitrogen was applied at planting. Quantitative agronomical data such as, days to maturity, stand count at harvest, plant height, number of pods per plant, number of seeds per pod, grain yield, thousand seed weight, and diseases reaction were collected.

\subsection{Statistical Analysis}

Data collected from the experiment were analyzed using SAS for ANOVA and Minitab Vrrsion 14 for the Multivariate analysis (cluster analysis). Analysis of variance (ANOVA) was performed according to the method described by Gomez and Gomez (1984) Correlations of the quantitative traits were determined using the Pearson correlation coefficient to identify the relationships between the traits. All quantitative and qualitative data were used for principal component analysis (PCA) and cluster analysis for all of the genotypes. The mean data were standardized prior to multivariate analysis to eliminate the effects resulting from using different scales. To separate the 32 genotypes into groups and to evaluate the patterns of similarity and dissimilarity, the data were subjected to cluster analysis according to Gower distance (Gower 1971), using PAST software version 2.15 (Hammer et al., 2001). Principal component analysis (PCA) of the correlation matrix was performed with the same software to determine the sources of variation among genotypes.

\section{RESULT AND DISCUSSION}

\subsection{Seed Size and Disease Reaction of Faba Bean Genotypes}

Since seed size, grain yield and disease reaction are the most important traits for pulse crops in general and faba bean crop in particular, analysis was focused to these characters, Based on this, there was high statistical significant difference $(\mathrm{P}<0.01)$ for thousand seed weight at Hashenge and Aiba 
Variability of Large Seeded Faba Bean Genotypes for their Yield and Yield Components in Water Logging Areas of Southern Tigray, Ethiopia

locations. Based on the analysis, genotype EH 06007-2 scored highest 1000 seed weight $(1111 \mathrm{gm})$ followed by EH 06088-6 ( 971.5 ) and EH 06007-4 (938.5 gm) over locations. On the other hand, least seed size was recorded from the local $(505.5 \mathrm{gm})$ genotype followed by the standard check Walki (587.3) and ET 07017-bulk (648.0 gm) genotypes. Seed size of faba bean crop is an important criteria for export market. From the tested genotypes, about 25 genotypes scored more 1000 seed weight than the standard check (Hachalu) but the other standard checks (Walki and local) showed least seed weight (Table 1),

In spite of the severity difference, occurrence of diseases is very challenging for pulse in general and faba bean in particular both at Aiba and Hashenge locations. Among them, Checolate spot, Ascochyta blight and the newly emerging disease called Faba bean gall are the most economical important diseases (Teklay et al., 2014). However, these diseases were not occurred in this year at Hashenge location. For this, disease severity scoring was taken from Aiba location for Checolate Spot and Ascochyta Blight (table 2).

Table1. Thousand Seed weight and disease severity score of Faba Bean Genotypes grown at Hashenge and Aiba, 2015

\begin{tabular}{|c|c|c|c|c|c|c|}
\hline \multirow[b]{2}{*}{ Genotype } & \multicolumn{3}{|c|}{ Thousand seed weight (gm) } & \multicolumn{3}{|c|}{ Disease Score at Aiba $(0-9)$} \\
\hline & Hashenge & Aiba & Mean & Checolate. Spot & Ascochyta Blight & Status \\
\hline EH 06007-2 & 1102 & 1120. & 1111.3 & 2.5 & 2 & $\mathrm{R}$ \\
\hline EH 06088-6 & 1012 & 931 & 971.5 & 4 & 3 & MR \\
\hline ET 07005-2 & 947 & 802.5 & 874.8 & 2.5 & 2.5 & $\mathrm{R}$ \\
\hline EH 06070-3 & 946 & 857.5 & 901.8 & 4 & 2 & MR \\
\hline ET 07005-1 & 937.5 & 815 & 876.3 & 4.5 & 2 & MR \\
\hline EH 06007-6 & 923 & 862 & 892.5 & 3 & 2.5 & MR \\
\hline EH 06022-1 & 906.5 & 706 & 806.3 & 3 & 2 & $\mathrm{R}$ \\
\hline EH 06088-1 & 900.5 & 843 & 871.8 & 2.5 & 2 & $\mathrm{R}$ \\
\hline ET 07002-bulk & 899.5 & 824 & 861.8 & 4.5 & 2 & MR \\
\hline EH 06028-1 & 872.5 & 918 & 895.3 & 4 & 2.5 & MR \\
\hline EH 06022-3 & 863.5 & 762 & 812.8 & 2 & 1.5 & $\mathrm{R}$ \\
\hline EH 06007-4 & 837.5 & 1039. & 938.5 & 3 & 1.5 & $\mathrm{R}$ \\
\hline ET 07005-3 & 836 & 883.5 & 859.8 & 2.5 & 1 & $\mathrm{R}$ \\
\hline EH 06022-4 & 835 & 792 & 813.5 & 4 & 2 & MR \\
\hline EK 05027-5 & 834 & 759 & 796.5 & 4 & 2.5 & MR \\
\hline ET 07002-2 & 834 & 776.5 & 805.3 & 5 & 3 & MR \\
\hline EH 06023-4 & 831.5 & 757.5 & 794.5 & 2.5 & 2 & $\mathrm{R}$ \\
\hline EH 06031-3 & 815.5 & 720 & 767.8 & 4 & 2.5 & MR \\
\hline New & 813 & 818.5 & 815.8 & 3.5 & 2.5 & MR \\
\hline EK 05024-2 & 810 & 833.5 & 821.8 & 3 & 2.5 & MR \\
\hline ET 07019-bulk & 804.5 & 808 & 806.3 & 3.5 & 3 & MR \\
\hline ET 07002-1 & 769.5 & 735.5 & 752.5 & 3.5 & 3 & MR \\
\hline EK 05023-1 & 766 & 668.5 & 717.3 & 2 & 1.5 & $\mathrm{R}$ \\
\hline Hachalu & 736.5 & 655.5 & 696.0 & 2.5 & 2 & $\mathrm{R}$ \\
\hline ET 07013-1 & 724.5 & 669 & 696.8 & 2.5 & 1.5 & $\mathrm{R}$ \\
\hline EK 05014-3 & 721 & 687 & 704.0 & 2 & 1.5 & $\mathrm{R}$ \\
\hline ET 07005-bulk & 715.5 & 751 & 733.3 & 3.5 & 3 & MR \\
\hline EK 05005-4 & 696.5 & 651 & 673.8 & 5 & 2.5 & MR \\
\hline EK 05002-3 & 685 & 591 & 638.0 & 3.5 & 2 & MR \\
\hline Walki & 647.5 & 527 & 587.3 & 4.5 & 2.5 & MR \\
\hline ET 07017-bulk & 642 & 654 & 648.0 & 4 & 3 & MR \\
\hline Local & 517 & 494 & 505.5 & 4 & 2.5 & MR \\
\hline S.E (m) & 50.2 & 47.94 & 48.01 & 0.97 & 0.62 & \\
\hline LSD (5\%) & $115.4 * * *$ & $110.2^{* * * *}$ & $44.2 * * *$ & NS & NS & \\
\hline CV (\%) & 6.14 & 6.21 & 6.04 & 29 & 27.6 & \\
\hline
\end{tabular}

$\mathrm{R}=$ resistant

MR = Moderately Resistant

As indicated in table 1, the severity of chocolate spot was more than ascochyta blight but 1 to 5 scale disease score observed for both diseases resulted in resistant to moderately resistant disease reaction. 


\section{Birhanu Amare Gidey}

Even though the standard and local checks resist moderate for both diseases, they showed higher disease scores for chocolate spot and ascochyta blight.

\subsection{Variations of Faba Bean Genotypes for Grain Yield}

The analysis of variance for grain yield has showed significant difference $(p<0.05)$ at Aiba location but no significant difference in the other location (Hashenge).. Based on the Aiba location, about 15 genotypes gave statistically more grain yield over the first standard check of walki (43.66 qt/ha). Accordingly, genotype ET 07013-1 gave the highest grain yield (59.31 qt/ha) followed by genotype ET 07005-1 (57.85) and EH 06088-1 (54.77 qt/ha).

Even though no statistical significant difference has showed for grain yield at Hashenge, the above genotypes (ET 07013-1, ET 07005-1 and EH06088-1) scored higher grain yield as 36.27, 38.08 and $35.14 \mathrm{qt} / \mathrm{ha}$ in that order.. In this location, the highest grain yielder gave $4218 \mathrm{qt} / \mathrm{ha}$, which indicated a very similar in yielding potential with the highest yielder genotype. In general, the genotypes that showed significant yield difference at Aiba had also higher and reasonable grain yield at Hashenge location (Table 2)

Table 2. Mean performance of Genotypes for Grain Yield at Aiba and Hashenge locations

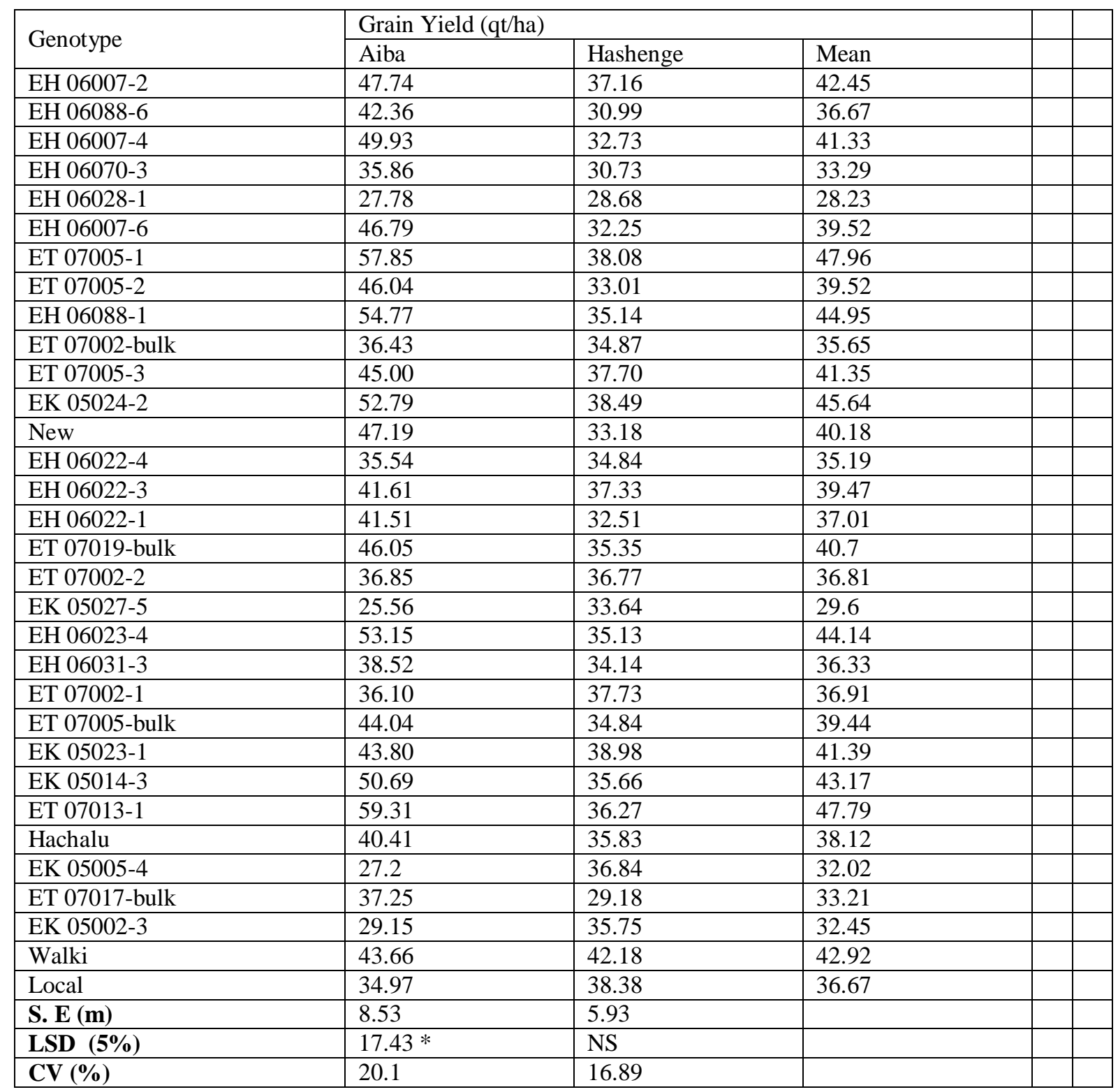

* implies significant difference at 0.05 ,

Levels connected with the same letters are not significantly different and NS stands for Nonsignificance 
Variability of Large Seeded Faba Bean Genotypes for their Yield and Yield Components in Water Logging Areas of Southern Tigray, Ethiopia

\subsection{Correlation Analysis}

Pearson correlation coefficients between different pairs of characters are computed and shown in table 4. The correlation coefficients of the 1000 seed weight trait showed that it was positively and significantly correlated $(\mathrm{P}<0.01)$ with days to maturity $(0.624)$, number of seeds per pod $(0.567)$ and number of tillers per plant $(0.427)$. On the other hand, thousand seed weight was highly and negatively correlated with number of pods per plant $(-0.487)$. As pods of faba bean per plant increases, seed size decreased to accommodate more pod clusters in a node..Similarly, highest and positive significant correlation was found between number of tillers per plant and days to maturity (0.679), number of seeds per pod and days to maturity (0.606).and grain yield with plant height (0.49). These results reflected the importance of days to maturity, number of seeds per pod and number of pods per plant in the determination of thousand seed weight in faba bean. Al Barri \& J Y Shtaya (2013) reported the importance of number of seeds per pod and number of pods per plant on 100 seed weight determination

Table 3. Pearson correlation coefficients for 8 quantitative traits of 32 faba bean genotypes grown in 2015 at Hashenge and Aiba

\begin{tabular}{|l|l|l|l|l|l|l|l|l|}
\hline Traits & DM & SCH & NTPP & PHT & NPPP & NSPP & GY & TSW \\
\hline DM & $\mathbf{1}$ & & & & & & & \\
\hline SCH & 0.085 & $\mathbf{1}$ & & & & & & \\
\hline NTPP & $0.679^{* * *}$ & -0.238 & $\mathbf{1}$ & & & & & \\
\hline PHT & 0.079 & 0.100 & 0.091 & $\mathbf{1}$ & & & & \\
\hline NPPP & $-0.377^{*}$ & -0.063 & 0.068 & 0.116 & $\mathbf{1}$ & & & \\
\hline NSPP & $0.606^{* * *}$ & 0.107 & $0.434^{*}$ & 0.223 & -0.220 & $\mathbf{1}$ & & \\
\hline GY & 0.072 & 0.087 & 0.272 & $0 . .493^{* *}$ & $0.369^{*}$ & 0.249 & $\mathbf{1}$ & \\
\hline TSW & $0.624^{* * *}$ & -0.214 & $0.427^{*}$ & -0.016 & $-0.487^{* *}$ & $0.567^{* * *}$ & 0.100 & $\mathbf{1}$ \\
\hline
\end{tabular}

DM: Days to mature; SCH: Stand Count at Harvest; NTPP: Number of Tillers per Plant: PHT: Plant height; NPPP: Number of pods per plant; NSPP: Number of seeds per pod; TSW: Thousand seed weight and GY for Grain yield

$* * *, * *$ and $*$ significant at $p \leq 0.001, p \leq 0,01$ and $p \leq 0.05$, respectively

\subsection{Cluster Analysis}

To evaluate the genetic variability or similarity of the genotypes among the clusters, the inter-cluster Gower distance and relationships were calculated using PAST software (Table 4). The highest distance (0.692) was between cluster V and IV, which suggested that the members of these clusters diverge on most of the studied traits and could be used in breeding programs. The lowest distance $(0.148)$ was between cluster III and cluster I, suggesting that their maternal origin may be very closely related (Kumar, et al., 2013)

Table 4. Gower distance and similarities among seven clusters of 32 genotypes of faba bean

\begin{tabular}{|l|l|l|l|l|l|l|l|}
\hline Cluster & I & \multicolumn{1}{|c|}{ II } & \multicolumn{1}{c|}{ III } & IV & V & VI & VII \\
\hline I & 0 & & & & & & \\
\hline II & 0.387 & 0 & & & & & \\
\hline III & $\mathbf{0 . 1 4 8}$ & 0.497 & 0 & & & & \\
\hline IV & 0.535 & 0.335 & 0.505 & 0 & & & \\
\hline V & 0.285 & 0.601 & 0.321 & $\mathbf{0 . 6 9 2}$ & 0 & & \\
\hline VI & 0.393 & 0.327 & 0.365 & 0.272 & 0.544 & 0 & \\
\hline VII & 0.370 & 0.580 & 0.346 & 0.465 & 0.444 & 0.378 & 0 \\
\hline
\end{tabular}

\subsection{Principal Component Analysis}

Principal Component Analysis (PCA) uses in identifying hidden patterns in the data and was performed to obtain more reliable information on how to identify groups of genotypes that have desirable yield traits for breeding. Eight components were extracted from the 8 studied traits by PCA analysis. But based on Diana (1999 as cited from Kaiser, 1960), factors to be retained should have more than 1 eigenvalues, at least 5\% variance explained for each component, and/or more than $75 \%$ cumulative proportion of variance explained. 
Table 5. Eigenvalues, proportion of variance and cumulative variance for 8 quantitative characters in Faba bean genotypes

\begin{tabular}{|l|l|l|l|l|}
\hline Character & PC1 & PC2 & PC3 & PC4 \\
\hline DM & -0.520 & 0.086 & -0.074 & -0.280 \\
\hline SCH & 0.038 & -0.104 & -0.791 & -0.471 \\
\hline NTPP & -0.429 & -0.152 & 0.389 & -0.385 \\
\hline PHT & -0.118 & -0.515 & -0.240 & 0.552 \\
\hline NPPP & 0.229 & -0.512 & 0.341 & -0.402 \\
\hline NSPP & -0.470 & -0.087 & -0.191 & -0.024 \\
\hline GY & -0.154 & -0.620 & -0.002 & 0.099 \\
\hline TSW & -0.482 & 0.200 & 0.080 & 0.274 \\
\hline Eigenvalue & 2.8847 & 1.7873 & 1.2303 & 0.7966 \\
\hline \% of Total variance & 36.1 & 22.3 & 15.4 & 10.0 \\
\hline Cumulative Variance & 36.1 & 58.4 & 73.8 & 83.7 \\
\hline
\end{tabular}

* DM: Days to mature; SCH: Stand Count at Harvest; NTPP: Number of Tillers per Plant: PHT: Plant height; NPPP: Number of pods per plant; NSPP: Number of seeds per pod; TSW: Thousand seed weight and GY for Grain yield

Accordingly, the results (Table 5) indicated that the first four components accounted for $83.7 \%$ of the total variation, whereas, the remaining 4 components accounted for only $16.3 \%$ of the morphoagronomic diversity. PC I explained the most variability $(36.1 \%)$, followed by PC II (22.3\%), PC III $(15.4 \%)$ and PC IV $(10.0 \%)$.. In the first principal component, DM, TSW, NSPP and NTPP were more important traits contributing more to the variation and this component was more associated with the high values of the above traits negatively. The sign indicates the direction of the relationship between the components and the characters (Yemane and Fasil, 2002). Due to more variation explained by the PC 1 (Table 5), its scores could effectively represent the genotype effect (Ali et al., 2011). In the second principal component, the observed variation (22.3\%) was caused mainly by GY, PHT, NPPP and TSW and of which, TSW had positive relationship with this PC. PC III was positively dominated by the effect of number of tillers per plant and number of pods per plant and negatively by stand count at harvest. On the other hand, Plant height, stand count at harvest and number of pods per plant in the fourth principal component constituted large part of the total variation. In this experiment, the PC analysis ultimately showed the amount of variability for the traits that could be used for the improvement of large seed sized faba bean genotypes.

\section{SUMMARY AND CONCLUSION}

The combined analysis of variance for thousand seed weight indicated that there was highly statistical significant ( $\mathrm{p}<0.01$ ) difference among genotypes over locations. Accordingly, genotype EH 06007-2 ranked highest seed size followed by EH 06088-6 and EH 06007-4 as 1111, 971.5 and 938.5 gram, respectively. The standard check (Hachalu) has showed lower thousand seed weight (696 gm) as compared with most faba bean genotypes under study. In addition, genotypes that out yielded the standard checks (Walki and Hachalu) in grain yield also have better seed size and lower disease reaction. The severity of diseases is very challenging for pulse in general and faba bean in particular both at Aiba and Hashenge locations. Among them, Checolate spot, Ascochyta blight and the newly emerging disease called Faba bean gall are the most economical important diseases. Disease severity scoring was taken from Aiba location for Checolate Spot and Ascochyta Blight.

Cluster analysis was used to further investigate the inter-relationships of the genotypes using eight agronomic traits. The genotypes were clustered in to 7 clusters which showed great variability among clusters of the genotypes and it uses for faba bean improvement. The implication of cluster analysis to growers and indeed to other users is that, a genotype can be selected from each of the seven clusters for cultivation with the objective of achieving the same yield differences in terms of proximate composition without having to examine all the genotypes. This is cost effective and time saving. Thousand seed weight and grain yield which has positive phenotypic correlation with some traits indicates choice based on the characters can improve these characters. .

Based on the inter-cluster Gower distance and relationships, the highest distance (0.692) was between cluster $\mathrm{V}$ and IV, which suggested that the members of these clusters diverge on most of the studied traits and could be used in breeding programs. The lowest distance $(0.148)$ was between cluster III 
and cluster I, suggesting that their maternal origin may be very closely related. Moreover, the PC analysis ultimately showed the amount of variability for the traits that could be used for the improvement of large seed sized faba bean genotypes.

\section{ACKNOWLEDGEMENT}

The author thanks Melkassa and Holleta Agricultural Research centers in providing the faba bean genotypes for planting materials. Thanks are also due to Alamata Agricultural research center in accommodating financial and service facilities during the research study. Indeed, I am extremely grateful to Mr Teklay Abebe, the center director and crop pathologist of Alamata Agricultural research center in his technical supporting related with this study. The author would also like to offer a great thanks to Mr Muez Mehari (Crop Core process of Alamata Agricultural Center) for his technical support in the designing and analysis parts.

\section{REFERENCES}

[1] Al Barri, T \& J Y Shtaya, M. (2013). Phenotypic Characterization of Faba Bean (Vicia faba L.) Landraces Grown in Palestine. Journal of Agricultural Science; Vol. 5, No. 2; ISSN 1916-9752 E-ISSN 1916-9760

[2] Ali, M. K., Akinci, C and Donmez, E. (2011). Assessment of genotype x environment interaction on yield and yield components of durum wheat genotypes by multivariate analyses. African Journal of Biotechnology. 10 (15), pp. 2875-2885, ISSN 1684-5315

[3] Barri, T. \& Shtaya, M.(2013). Phenotypic Characterization of Faba Bean (Vicia faba L.) Landraces Grown in Palestine. Journal of Agricultural Science; Vol. 5, No. 2;

[4] Beniwal, S. and Dereje Gorfu (1987). Disease of Faba bean in Ethiopia EPC Newsletter

[5] Biruk Bereda (2009). Production and Marketing Activity of Broad Bean in Ethiopia. Ethiopia Commodity Exchange Authority reoprt. pp. 10 - 11

[6] Central Statistical Agency (CSA. 2013). Report on area and production of major crops (private peasant holdings, meher season). Vol. I. Statistical bulletin 532. pp. 10-14

[7] Couchman, J.and Hollaway, K. H. (2016). Victorian Winter Crop Summary 2016. Available from: http://www.grdc.com.au/NVT-Victorian-Winter-Crop-Summar. [Date accessed: April 26, 2016].

[8] Diana, D. S. (1999). Principal Component Analysis vs. Exploratory Factor Analysis. Pp. 203230, University of Northern Colorado

[9] Getachew Agegnehu, Asnake Fikre and Ayalew Taddese (2003). Cropping Systems, Soil fertility and Crop Management Research on Cool-season Food Legumes in the Central Highlands of Ethiopia. In: Kemal Ali, Gemechu Kenneni, Seid Ahmed, Rajeandra, S, Beniwal, S., Makkouk, K.and Haiiia, M. (Eds). Food and Forage Legumes of Ethiopia: Progress and Prospects. Proceedings of the Workshop on Food and Forage legumes, 22 - 26 September 2003 (pp 135 178). Addis Ababa, Ethiopia.

[10] Gomez, K.A. and A.A. Gomez, 1984. Statistical Procedure for Agricultural Research (2 ${ }^{\text {nd }}$ Ed.). John Wiley and Sons, New York.

[11] Gower, JC (1971). A general coefficient of similarity and some of its properties. Biometrics. 27: 857-871

[12] Hammer $\varnothing$, Harper DAT, Ryan PD (2001). PAST: paleontological statistics software package for education and data analysis (version 2.15). Palaeontologia Electronica. 4:9

[13] Kumar, R, G., Sreewongchai, T., Nakasathien, S. and Phumichai, C. (2013). Phenotypic variation and the relationships among jute (Corchorus species) genotypes using morphoagronomic traits and multivariate analysis Australian Journal of Crop Science. 7(6):830-842, Bangkok 10900, Thailand

[14] MoARD (2008). Animal and Plant Health Regulatory Directorate: Crop Variety Register, Issue No. 12. Addis Ababa, Ethiopia

[15] Tekalign Mamo, Richter, C. and Heiligtag, B. (2002). Phosphorus Availability Studies on Ten Ethiopian Vertisols. Journal of Agriculture and Rural Development in the Tropics and Subtropics. Volume 103, No. 2, 177-183 
[16] Teklay Abebe, Tsehaye Birhane, Yemane Nega and Assefa Workineh (2014). The Prevalence and Importance of Faba Bean Diseases with Special Consideration to the Newly Emerging "Faba Bean Gall in Tigray, Ethiopia. Discourse Journal of Agriculture and Food Sciences. ISSN: 2346-7002 Vol. 2(2): 33-38

[17] Temesgen Alene and Aemiro Bezabih (2012). Genotype X Environment Interaction and Stability Analysis of Faba Bean (Vicia faba L.) Varieties in North Ethiopia. Libyan Journal International, ISSN 2219-4304, 3 (4): 195-200.(C IDOSI

[18] Yemane Tsehaye and Fassil Kebebew (2002). Morphological diversity and geographic distribution of adaptive traits in finger millet (Eleusine coracana (L.) Gaertn. Subsp. coracana [Poaceae]) populations from Ethiopia. Addis Ababa, Ethiopia. 